\title{
COOPERATION BETWEEN SCIENTISTS AND ENTREPRENEURS OF ZEMGALE
}

Ginta Kronberga ${ }^{1}$, Dr.sc.soc., assist.prof.; Madara Ratkevica ${ }^{2}$, student

1,2Latvia University of Life Sciences and Technologies

\begin{abstract}
Collaboration between scientists and entrepreneurs is a prerequisite for knowledge transfer and place development, creating opportunities for entrepreneurs to develop or improve production and service delivery, as well as quality, by finding innovative approaches to common practice. Scientists, facing new challenges and solutions to them, have the opportunity to showcase their research capacity as well as to introduce stakeholders and the general public with their ideas and solutions. Using a qualitative approach, the authors focused on one of the planning regions of Latvia - Zemgale. The aim of the article is to investigate the problems and solutions of cooperation between entrepreneurs and scientists in Zemgale from the perspective of the involved parties. The tasks are related to the theoretical characterization of scientists and entrepreneurs, as well as cooperation, taking into account the specifics of Zemgale region. The results show that scientists, Zemgale entrepreneurs and experts of the Technology Transfer Centre of Latvia University of Life Sciences and Technologies are directly involved in the implementation of cooperation between scientists and entrepreneurs in Zemgale region. Collaboration is based on the achievement of specific objectives; and the promotion of cooperation in different scenarios varies. It should also be concluded that there are several problems in the attempted cooperation between scientists and entrepreneurs, but the most important are interrelated: the knowledge brokerage in Zemgale region is not one of the priorities; the number of scientists and the quantity of technical equipment are not always sufficient to meet the demand for scientific services; and entrepreneurs are little informed of scientific services, scientific capacity in Zemgale region, therefore they are cautious at the planning stage of cooperation.
\end{abstract}

Keywords: scientists, entrepreneurs, cooperation.

JEL code: $018 ; 030$.

\section{Introduction}

Co-operation between scientists, researchers and entrepreneurs has long been discussed in Latvia, but these discussions have rarely led to significant changes. Co-operation between these two groups of people would contribute to the productivity of different companies (Tisenkopf, Bela, Kunda, 2011; Adamsone-Fiskovica, 2012). Not only is Zemgale considered to be the most fertile region in Latvia, it also has great scientific resources; Zemgale also has business and logistics centres, and it is strategically located - we can talk about different industries that could be supported by appropriate scientific props (Tisenkopfs, Bela, Kunda, 2011; Zemgales planosanas ..., [s.a.]a; Zemgales planosanas ..., [s.a.]b). Currently, cooperation is also promoted from outside - by financial and nonfinancial means. However, there is a problem: in Latvia, including Zemgale, cooperation between entrepreneurs and scientists is not adequate. The productivity of the Latvian economy is significantly lower than in other European countries, and there are only a few (mostly low added value - auth.) sectors that do not fit the pattern (Ekonomikas ministrija, 2017). Exception areas (positive examples) are animal husbandry and grain production, which, when having appropriate investments, show good results - these are the sectors that have historically experienced the positive impact of innovation on entrepreneurship. The low level of economic productivity is directly related to the lack of scientific input in enterprises; they are not able to compete with the products and services of those countries that have cheaper labour. Scientific associations believe that scientific capacity in terms of both quality and number of scientists in Latvia is sufficient; also the specialization of scientists is broad enough to be used by various enterprises. So this problem situation can be characterized from two sides. The potential of scientists is not sufficiently exploited in business. In turn, entrepreneurship

\footnotetext{
1 Tel.: + 371 29390994, E-mail address:Ginta.Kronberga@llu.Iv

2 Tel.: +371 22045454, E-mail address:madara.ratkevica@gmail.com
} 
lacks creativity (Gulbinska, 2017; Paiders, 2017). From a scientific point of view, the topic in social sciences is current because of the many aspects of this co-operation, but the subject is relatively little researched, especially in quantitative terms. The results of the study are particularly relevant to institutions and organizations that are involved in promoting cooperation, as well as scientists and entrepreneurs. Facilitating knowledge transfer, information and understanding of collaborative issues and possible solutions are helpful in addressing collaborative matters and understanding between stakeholders.

The aim of the article is to investigate the problems and solutions of cooperation between entrepreneurs and scientists in Zemgale region. The main research questions of the thesis are: 1. Who is involved in the implementation of cooperation between scientists and entrepreneurs in Zemgale region and in what manner? 2. How does the promotion of cooperation take place - what benefits are presented to scientists - and what to entrepreneurs? 3. What are the main problems and possible solutions related to the implementation of cooperation between scientists and entrepreneurs in Zemgale region? The goals set for the purpose of the research are related to the outline of the essence of the cooperation theory, which will be used when studying actions and decisions on the implementation of cooperation between scientists and entrepreneurs; to provide theoretical explanation of scientists and entrepreneurs as a social group and to conduct empirical research on the problems and solutions of collaboration between scientists and entrepreneurs in Zemgale region.

\section{Research results and discussion}

\section{Theoretical aspects of collaboration between scientists and entrepreneurs}

Scientist is an academically highly educated individual who collects information, researches, analyses, draws conclusions and makes discoveries, as well as conducts experiments to achieve the goals set for scientific work. From a sociological point of view, science is treated as a social phenomenon, just like entrepreneurship; it is described as a social activity (Bruce, Yearley, 2006; Shapin, 1995).

The prestige of the profession of scientists or public dignity is a significant aspect (AdamsoneFiskovica, 2012). Society evaluates scientists on their own ideas. The level of education of an individual has a significant impact on the measure of the popularity of science (Tisenkopfs, Bela, Kunda, 2011). Thus, only an educated individual can appreciate the importance of education (including the contribution of science). There is a problem here: if the intellectual level of society is low, then it has No value for knowledge; to change it, it is necessary to educate the public, but it has No motivation to learn, because education has No value in its eyes. This is why social perceptions of science in society, where social and humanitarian sciences and their contribution to the understanding of processes in society are seen as helpful, are important here.

The concept of an entrepreneur has a significant link to the understanding of entrepreneur as a social category. This word is derived from the French word entreprendre, which in translation means "do something". In the Middle Ages, this term was used to refer to "an active person getting (something) done". In later years, this term has been redesigned and expanded to include the terminology of economic science. Theories of economics were built around this concept, but attempting to do so revealed that entrepreneurship is a phenomenon that social sciences are better able to explain (Swedberg, 2000). From this point of view, entrepreneurship is represented as a 
response of socio-economic processes. It explores the role of the entrepreneur and its influencing factors from different perspectives (Thornton, 1999).

The Latvian entrepreneur is interesting for an atypical planning style - he envisions well what he wants to see in his company in the future, but is rarely able to set up and more rarely fulfil the planned tasks to achieve his goals. At present, the scientific contribution is practically topical for those businessmen with greater experience, who not only maintain but also develop the functions of their company. But only innovative entrepreneurship is potentially competitive (Tisenkopfs, Bela, Kunda, 2011). And only such business practices can be sustainable.

The role of an active entrepreneur in a business is very similar to that of a researcher in research. Both groups are also characterized by peculiarities of professional socialization, and they can be an obstacle for possible interaction. Partly this attitude - "not worth it" - has also been promoted by the tradition of anti-intellectualism, and these groups have not had enough time to interact with each other, so other agents, such as knowledge brokers, knowledge transfer centres, etc. are often involved in promoting collaboration between scientists and entrepreneurs.

Cooperation is a phenomenon in which several individuals or groups work together to form a strategic alliance. A strategic association is a deliberate inter-organizational cooperation designed to benefit its partners and stakeholders (Gajda, 2004). Cooperation is a set of interactions of different nature - it can include conflicting, adapting and coercing - reconstructing one's individual social reality (Adler, 2009).

The theory of co-operation can be interpreted in different ways, but the fullest understanding of this concept involves co-ordination, co-operation and working together (Gajda, 2004; Bite, 2012; Kronberga, 2014). So this concept is an intense and versatile form of collaboration characterized by common goals, including benefits, involving multiple individuals, mutual trust, respect, understanding and diversity of knowledge and practice (Bite, 2012). Cooperation is referred to as a kind of phenomenon that occurs only if the preconditions mentioned above coincide with the agents. Cooperation can be explored both as a goal and as a process (Kronberga, 2014). Cooperation is also characterized by its stages of development and levels appropriate to the degree of integration: coexistence, communication (introduction, etc.), coordination (planning, etc.), collaboration and coadunation (continuation of cooperation) (Bite, 2012; Kronberga, 2014). Collaboration could also be described as positively-oriented competition - so the co-operation also determines particular type of behaviour - whether it is only for its own benefit, for the benefit of someone else (for example, an entrepreneur) or a common public good (Tjosvold, 1984; Knopf, 2016). Differences between concepts cooperation and collaboration could be explained through different levels of integration: cooperation as working simultaneously whilst sharing information etc.; collaboration as united and fully integrated co-working with a common goal.

In Latvia, entrepreneurship and science function as separate entities, and the relationship between research and practice should be better targeted with the help of knowledge brokerage. In a sociological sense, it is not just the "selling" of knowledge, but the introduction of elements of one practice into another practice, overstepping the boundaries between scientific disciplines, economic areas, practice competences and other barriers (Tisenkopfs, Bela, Kunda, 2011). The realization of cooperation is influenced by various factors: the prestige of science and scientists in society, popularity of certain branches of science, social perceptions of science, public trust in scientific research, as well as initiative and financial possibilities of organizations (Adamsone-Fiskovica, 2012). 
Already today, the role of universities in promoting cooperation is recognized not only in the context of exact sciences but also in social (and humanitarian) sciences. Higher education institutions, their branches and research institutions play a central role in the regions. Their task would be to function according to the needs of the region. Latvia University of Life Sciences and Technologies is a resource for the Zemgale region as it has several scientific institutes as well as a Technology and Knowledge Transfer Centre. However, attention should be drawn to the possibility that entrepreneurs, knowing the extent and competence of their financial and human resources, may not benefit from the attraction of one partner (scientist) and the benefits of such cooperation.

\section{Research methodology}

Partly structured interviews and expert interviews based on a qualitative research approach are analyzed in the article. The research sample is based on the principles of a targeted sample, partly also using the snowball method. Interviews took place in informant workplaces between March 13, 2018 and May 7, 2018. Interviews lasted from 25 minutes to 1 hour 9 minutes. The article analysis is based on: 1 ) the views of 6 entrepreneurs ( 4 of the interviewed entrepreneurs wanted to remain anonymous; therefore, other entrepreneurs will not be revealed within the article. All are from Zemgale region and represent both production and service sphere); 2 ) the opinions of 2 scientists of the University of Life Sciences and Technologies of Latvia (who have experience in cooperation with entrepreneurs of food technology and construction industry); and 3) the views of 2 experts - Sandra Muizniece-Brasava, Head of Technology and Knowledge Transfer Department, and Ieva Silina, Chairman of the Board of Latvian Young Scientists' Association, that have been focusing on identifying cooperation problems and possible solutions.

\section{Implementation of cooperation between scientists and Zemgale entrepreneurs from the perspective of the stakeholders}

So far, many attempts have been made to solve cooperation problems between entrepreneurs and scientists in Latvia (including University of Life Sciences and Technologies of Latvia). University of Latvia has organized a seminar on cooperation of scientists with entrepreneurs, EU funds have financed the program "Entrepreneurship and Innovations", Latvian Association of Young Scientists has repeatedly organized meetings to promote cooperation of scientists and entrepreneurs, also other institutions like LAS; The Association of Local and Regional Governments of Latvia and individual municipalities occasionally (also regularly) organize various co-operation activities.

One of the main problems of Latvia that hinders possible cooperation of entrepreneurs and scientists could be low activity in intellectual property creation and lack of respect for intellectual property, therefore it is necessary to promote not only the public interest, but to find the necessity - to create in entrepreneurs the need (desire) for scientific contribution.

Judging by the planning documents of Zemgale Planning Region, the task of realizing innovations and cooperation in education, creativity and entrepreneurship, as well as promoting cooperation in Zemgale region is indirectly delegated to the University of Life Sciences and Technologies of Latvia, including Technology and Knowledge Transfer Centre. This implies an obligation for the university to take care of the cooperation of scientists and entrepreneurs and to promote it in the Zemgale region (Zemgales planosanas..., [s.a.]c; Zemgales planosanas..., [s.a.]d; Zemgales planosanas..., [s.a.]e).

It should be noted that the sampled entrepreneurs have experience of cooperation (scientistentrepreneur). For some companies, cooperation was required as a mandatory condition within the project to be implemented. As entrepreneurs admit, some of them have initially formed their own 
businesses on a personal or available scientific basis, but 2 informants admit that they have collaborated with scientists not only in their own personal interest, but also to help young scientists conduct the research necessary for the learning process.

Since the personal knowledge base of the individual is already important in the development of cooperation, it is natural for scientists to observe that the courses offered to the general public by the university often serve as a basis for potential future collaboration (e.g., courses offered by Faculty of Food Technology to home producers). Most companies turn to scientists or scientific institutions for help in solving a particular problem. Scientists rely on entrepreneurial interest and relationships in the decision-making process - communication that develops during the co-operation (including its planning). Due to the fact that the research has analysed examples of cooperation, it is logical that the experience of co-operation from the entrepreneurs in most cases is evaluated positively, but the experience of scientists (incl. experts) has been very different.

Entrepreneurs are rather uninterested in events and institutions that promote the cooperation of scientists and entrepreneurs. Scientists rely on the university they are attached to - that it will enable them to work with entrepreneurs. The fact that the entrepreneur's initiative plays a decisive role in the creation of the cooperation is shared by the parties involved and indicates that it is essential for the entrepreneur to understand his need. However, entrepreneurs express a desire for greater interest from scientists and scientific institutions in business potential and collaboration. This can be explained by the fact that awareness raises a greater sense of security - also confidence in cooperation initiatives. Especially when it comes only to initial information - offer, approximate costs, opportunities - where information should be more freely available, so there should be informative, demonstrable examples from the scientific institutions in terms of costs and ideas.

The capacity of scientific human resources is often insufficient. This is pointed out by the expert S. Muizniece-Brasava and the interviewed scientists, as well as some of the entrepreneurs. They also point out that the lack of time is relative, as it depends on the set priorities, referring to the workload of scientists in lecturing and ensuring their academic development (entrepreneurs feel that they bother scientists with their requests - a desire for a scientific service).

Looking at cooperation problems in-depth at university level, we come to the knowledge brokerage, whose principles lead us to conclude that the lack of co-operation is also related to the problems of formation of scientific succession at the level of higher education in Latvia in general. It is assumed that the lack of practical co-operation between entrepreneurs and scientists could also be rooted in a stagnant training system (it does not encourage business confidence in the quality of scientific services).

The entrepreneurs interviewed in the research have encountered an unsatisfactory situation in the supply of scientific services. According to entrepreneurs, the practice of scientific services is outdated, scientifically insufficient and general (lack of specialization). There are spheres in which Latvian scientists have not reached a sufficiently high level of knowledge, but there is also a disagreement among informants - scientists and entrepreneurs tend to have different expectations regarding the outcome of the research (e.g., product quality against expiration dates). Scientists and entrepreneurs have different priorities, including differences in the value systems of the representatives of social groups: if the development of a scientist is predominantly rooted in the desire to explore and discover, then entrepreneurship is based on the goal of earning.

The research also reveals a deeper problem in the field of science in Latvia, also on the background of examples from other countries: 1) awareness of the duty of the future specialists to inform the 
public is not promoted; 2 ) there are No systems of scientific advancement management (although the operation of such a system may need to be reassessed as it may exclude qualitative research that provides data that is not otherwise obtainable in current technological development but is vital for research); 3) Scientific saturation of the business sector as the only solution to the challenges of aging and poverty. However, here it is important to determine whether the society understands the nature of science (method), its task and whether it does not expect the "miracles" from it unreasonably. In the absence of openness among scientists, not only misconceptions about the ability and scientific capacity of scientists, but also its availability is created - in this case the realization of co-operation opportunities decreases and hopes for increased productivity are essentially futile.

Not always funding projects that integrate science into business support high-level, complex research. If research is promoted (financed) only from the point of view of the co-promoters in (economically) safe research, the development of science is slowed down deliberately. Several respondents also question the usefulness of the projects due to the extensive requirements and bureaucracy.

The study revealed that there are serious problems with the awareness and availability of scientific services. Informants have also stated that the inappropriate focus of business development is set at the planning level of Zemgale region municipalities and Zemgale region in whole.

From the point of view of scientists and businessmen, practically applicable scientific research, not general research activity in science, is essential for the development of cooperation. In this respect, the faculties of the University of Life Sciences and Technologies of Latvia offer students to choose the topics of study papers and final theses on issues that are relevant in the field of professional activity in general or in the region. Concerning the cooperation activity in the Zemgale region, it should be concluded that the cooperation is rather unsatisfactory, as there are few examples of co-operation.

Cooperation problems and their solutions from the point of view of stakeholders. Informants who have their own scientific experience are aware that the scientific contribution to the development of the business sector can be highly visible and also profitable in terms of return - the economic opportunity is felt in a short period of time, therefore Zemgale entrepreneurs consider the costs of scientific services to be acceptable, but the services are insufficiently modern, as evidenced by the willingness of entrepreneurs to pay more for more advanced research approaches. Entrepreneurs' opinion points to the fact that the promotion of co-operation could be ensured by unique and modern scientific services, so the solution of the situation requires a broad spectrum of scientific services.

Experts, looking from the outside, recommend non-formal activities as an incentive for networking.

In the event that the supply of scientists does not satisfy Latvian entrepreneurs to such an extent that their services become less topical, both scientists and experts see the possibility to sell scientific services in the international market, which could also have a positive effect on cooperation between scientists and entrepreneurs.

In the course of the interviews, as another solution to the problem, which is more directly related to the Zemgale region, there was an idea of cooperation of scientists with builders of production equipment, thus creating high value added production equipment for the entrepreneur.

Entrepreneurs have proven in their experience that external compulsion mechanisms can successfully integrate scientists (or its services) into business. This practice is included in the 
European Structural Funds projects and is seen by entrepreneurs as an effective solution to the problem.

Summarizing the main findings of the research, answers to the research questions are found:

1. Scientists, Zemgale entrepreneurs and experts of the Technology Transfer Centre of Latvia University of Life Sciences and Technologies are directly involved in creating collaboration between scientists and entrepreneurs in Zemgale region. Cooperation is based on the achievement of specific objectives.

2. In different scenarios, the promotion of cooperation varies:

- Promoting cooperation by providing financial support to entrepreneurs takes place through LIDA support programs for entrepreneurs, which requires the involvement of a scientist as a mandatory condition for obtaining funding.

- In cases where collaboration is promoted by a prospective scientist working in the company, the entrepreneur is given the opportunity to gain scientific input with minimal time and financial expenses; the benefit for a scientist is the chance to carry out the necessary research to achieve academic goals.

- At the camps organized by the Young Scientists' Association, scientists and entrepreneurs are offered the opportunity to get in touch, get ideas and communicate in an informal atmosphere, offering meaningful leisure opportunities for all parties involved.

3. There are many problems in creating collaboration between scientists and entrepreneurs, but the most important ones are related: since knowledge brokering is not a priority for LUA, the number of scientists and technical equipment is not sufficient to satisfy the demand for scientific services, as entrepreneurs are little aware of scientific services, therefore they are cautious of it from the beginning.

\section{Conclusions, proposals, recommendations}

1) Science promotion and knowledge brokerage can play a crucial role in the realization of knowledge, interdisciplinary knowledge transfer and collaboration, as well as in the interaction between scientists and other groups in society, thus creating social insights into science.

2) Lack of entrepreneurial interest in collaboration with scientists can be explained by the use of "outdated" methods in the solutions offered by scientists, the deficiencies of technical equipment of scientific institutions; furthermore, the historical background has had a negative impact on the development of current science in Latvia; multiple changes in Zemgale region's business focus directions over the past hundred years have created confusion about the priorities on individual, but also regionally, on institutional level.

3) Finding information for an entrepreneur without accumulated contact base can be seen as very weak - lack of informative references and difficult communication make the planning phase of cooperation chaotic, time-consuming and generally ineffective.

4) Attracting European Union funds for project implementation ensures collaboration between scientists and entrepreneurs as a mandatory condition for obtaining funding.

5) In collaborative projects, entrepreneurs in Zemgale often choose not to engage: the entrepreneur is given too short a time to wait for their turn for scientific services, and involvement in the project is too time-consuming, complicated and unsafe in terms of both wasted resources and copyright (patents). 
6) The scientific capacity of human resources at the university is not sufficient for the development of knowledge brokerage - scientists are too busy with their daily duties to be able to engage in effective cooperation with entrepreneurs.

7) There is a lack of data on regional innovation, but the available data are considered obsolete. In order to find out why cooperation between scientists and businessmen in Zemgale region is not sufficient, it is necessary to carry out more research, finding out the opinion of Zemgale entrepreneurs who have not cooperated so far, as well as those of Zemgale entrepreneurs who have decided to move or start their activity in another region.

8) In order to stimulate the interest of entrepreneurs in cooperation with scientists, it is necessary to improve the availability of information for future cooperation partners - each faculty would need to develop an offer of scientific services for entrepreneurs, which (in an easily visible form) would be available on university and faculty websites, including: 1) available scientific services, 2) approximate service prices or examples of costs for scientific services and 3 ) inventory of materials and technical equipment, etc.

9) In order to promote the transfer of knowledge for profit, the university must identify, evaluate its confidence in the supply of scientific services, and compare it with the supply of other countries and assess the possibilities of investing in technology: 1 ) if it is not possible to invest in technical support, then (while taking care of the succession of knowledge), it is necessary to promote the retention of new potential scientists at the university with a motivating pay system for human resource development - in this scenario, offering the services (as comparatively cheaper) in other countries; 2) if priority is given to regional (and / or local) cooperation and joint development, long-term investment in both the material and technical resources and human resources and their training must be made.

\section{Bibliography}

1. Adamsone-Fiskovica A. (2012) Zinatnes un sabiedribas attiecibas Latvija: komunikativas prakses un diskursi (Science and Society Relations in Latvia: Communicative Practices and Discourses). Retrieved: https://www.szf.lu.Iv/fileadmin/user_upload/szf_faili/Petnieciba/promocijas_darbi/AdamsoneFiskovica \%20Promocija_aizsargats.pdf Access: 10.12.2017.

2. Adler P.S. (ed.) (2009) The Oxford Handbook of Sociology and Organization Studies: Classical Foundations. Oxford: Oxford University Press. 679 p.

3. Bite D. (2012) Pasvaldibu sadarbiba Latvija (Local Government Cooperation in Latvia). Retrieved: https://www.szf.lu.Iv/fileadmin/user_upload/szf_faili/Petnieciba/promocijas_darbi/Dina \%20Bite \%202012.p df Access: 02.07.2018.

4. Bruce S., Yearley S. (2006) The Sage Dictionary of Sociology. London: Sage Publications. 328 p.

5. Ekonomikas ministrija (Ministry of Economics) (2017) Aseradens: 2017. gada ir javeido jauns inovativas ekonomikas modelis (Aseradens: In 2017, We Need to Develop a New Innovative Economic Model). Retrieved: https://em.gov.lv/lv/jaunumi/13219-aseradens-2017-gada-ir-javeido-jauns-inovativasekonomikas-modelis Access: 10.03.2018

6. Gajda R. (2004) Utilizing Collaboration Theory to Evaluate Strategic Alliances. American Journal of Evaluation, Vol. 25, No. 1, pp. 65-77

7. Gulbinska P. (2017) Zinatnieku un uznemeju sadarbiba - situacija Latvija (Cooperation Between Scientists and Entrepreneurs - Situation in Latvia). Retrieved: http://Ir1.Ism.Iv/lv/raksts/zinamaisnezinamaja/zinatnieku-un-uznemeju-sadarbiba-situacija-latvija.a89671/ Access: 02.12.2017

8. Knopf W. J. (2016) International Cooperation on WMD Nonproliferation. Retrieved: https://books.google.Iv/books?id=Rg7UCgAAQBAJ\&pg=PA6\&lpg=PA6\&dq=cooperation+theory\&source=bl\& ots $=$ KrLuOZwwZx\&sig=sDC_-

LBhJy1yMUkBz3PThysYZNA\&hl=en\&sa=X\&ved=0ahUKEwjBtvyylcnYAhUMEiwKHR6QCnA4HhDoAQg7MAI\#v= onepage\&q=cooperation \%20theory\&f=false Access: 31.12 .2018

9. Kronberga G. (2014) Augstskolas zinasanu parnese Latvija (Universities in Knowledge Transfer in Latvia). Retrieved:

https://www.szf.lu.Iv/fileadmin/user_upload/szf_faili/Bauhausi/Kronberga_Ginta_Augstskolas_zinasanu_par nese_Latvija_2014_pdf.pdf Access: 10.12.2017. 
10. Paiders J. (2017) Kapu zvans inovaciju atbalstam! (Tomb Call for Innovation Support!). Retrieved: http://nra.Iv/latvija/juris-paiders-3/222775-kapu-zvans-inovaciju-atbalstam.htm Access: 10.12.2018.

11. Shapin S. (1995) Here and Everywhere - Sociology of Scientific Knowledge. Annual Review of Sociology 21 pp. 289-321. Retrieved: https://pdfs.semanticscholar.org/2829/a6eb141434877e67d60b1b60a04ac0e484ac.pdf Access: 11.01.2018.

12. Swedberg R. (2000) The Social Science View of Entrepreneurship: Introduction and Practical Applications. Retrieved: http://people.soc.cornell.edu/swedberg/2000 \%20The \%20Social \%20Science \%20View.pdf Access: 11.01.2018.

13. Thornton H. P. (1999) The Sociology of Entrepreneurship. Retrieved: https://www.researchgate.net/publication/228697727_The_Sociology_of_Entrepreneurship_Annual_Review _of_Sociology Access: 10.01.2019.

14. Tisenkopfs T., Bela B., Kunda I. (red.) (2011) Augstskolas regionos: zinasanu un prakses mijiedarbe (Universities in Regions: Interaction of Knowledge and Practice). Riga: SIA Apgads "Zinatne". 495 Ipp

15. Tjosvold D. (1984) Cooperation Theory and Organizations. Retrieved: https://www.researchgate.net/publication/247716944_Cooperation_Theory_and_Organizations Access: 02.01.2019.

16.Zemgales planosanas regiona attistibas programma 2015-220. Strategiska dala (Zemgale Planning Region Development Program 2015-220. Strategic Part) [s.a.]d. Retrieved: https://www.zemgale.Iv/index.php/attistibas-planosana/planosanas-dokumenti/category/35-zpr-attistibasprogramma-2015-2020 Access: 24.05.2018.

17.Zemgales planosanas regiona ilgtspejigas attistibas strategija 2015-2030, attistibas programma 2015-2020 ESOSAS SITUACIJAS RAKSTUROJUMS (Zemgale Planning Region Sustainable Development Strategy 20152030, Development Program 2015-2020 DESCRIPTION OF EXISTING SITUATION) [s.a.]a. Retrieved: https://www.zemgale.Iv/index.php/attistibas-planosana/planosanas-dokumenti/category/37-zpr-esosassituacijas-analize Access: 24.05.2018.

18.Zemgales planosanas regiona ilgtspejigas attistibas strategija 2015 - 2030 (Zemgale Planning Region Sustainable Development Strategy 2015-2030) [s.a.]b. Retrieved: http://www.jelgava.Iv/files/2_zpr_ias.pdf Access: 10.12 .2017 . 